Article

\title{
Antifungal Activity of Beauveria bassiana Endophyte against Botrytis cinerea in Two Solanaceae Crops
}

\author{
Lorena Barra-Bucarei ${ }^{1,2}, * \mathbb{0}$, Andrés France Iglesias ${ }^{1}$, Macarena Gerding González ${ }^{2}$, \\ Gonzalo Silva Aguayo ${ }^{2}$, Jorge Carrasco-Fernández ${ }^{1}$, Jean Franco Castro ${ }^{1}$ and \\ Javiera Ortiz Campos ${ }^{1,2}$ \\ 1 Instituto de Investigaciones Agropecuarias (INIA) Quilamapu, Av. Vicente Méndez 515, Chillán 3800062, \\ Chile; afrance@inia.cl (A.F.I.); jorge.carrascof@inia.cl (J.C.-F.); jean.castro@inia.cl (J.F.C.); \\ javiera.ortiz@endofitos.com (J.O.C.) \\ 2 Facultad de Agronomía, Universidad de Concepción, Vicente Mendez 595, Chillán 3812120, Chile; \\ mgerding@udec.cl (M.G.G.); gosilva@udec.cl (G.S.A.) \\ * Correspondence: lbarra@inia.cl
}

Received: 11 December 2019; Accepted: 28 December 2019; Published: 31 December 2019

\begin{abstract}
Botrytis cinerea causes substantial losses in tomato and chili pepper crops worldwide. Endophytes have shown the potential for the biological control of diseases. The colonization ability of native endophyte strains of Beauveria bassiana and their antifungal effect against $B$. cinerea were evaluated in Solanaceae crops. Root drenching with B. bassiana was applied, and endophytic colonization capacity in roots, stems, and leaves was determined. The antagonistic activity was evaluated using in vitro dual culture and also plants by drenching the endophyte on the root and by pathogen inoculation in the leaves. Ten native strains were endophytes of tomato, and eight were endophytes of chili pepper. All strains showed significant in vitro antagonism against $B$. cinerea (30-36\%). A high antifungal effect was observed, and strains RGM547 and RGM644 showed the lowest percentage of the surface affected by the pathogen. Native strains of B. bassiana colonized tomato and chili pepper tissues and provided important levels of antagonism against B. cinerea.
\end{abstract}

Keywords: entomopathogenic fungi; biological control; antifungal activity; Solanum lycopersicum; Capsicum annuum

\section{Introduction}

Among the phytosanitary problems affecting crops in the Solanaceae family, such as tomato (Solanum lycopersicum L.) and chili pepper (Capsicum annuum L.), fungal diseases that produce economic losses are highlighted. Intensive production systems, like greenhouse cultivation, high temperatures, and humidity, favor disease development and dissemination [1]. Botrytis cinerea is the etiological agent of grey mold, which affects more than 200 plant species and is the most frequent disease in the cultivation of tomato and chili pepper worldwide. This fungus can penetrate wounds and colonize the whole aerial part of the plant [2], affecting the whole growing cycle and postharvest [1] and reducing fruit yield and quality. In greenhouse conditions, B. cinerea enters the tissue through pruning cuts, leaves, and flowers. In turn, damage to the fruits occurs largely at postharvest [2,3].

Botrytis cinerea is difficult to control because it can infect using different strategies and use different hosts as its inoculum source because it can survive as mycelia, conidia, and/or sclerotia for long periods of time in crop residues and in the soil. Chemical fungicides are intensively used for its control; however, there is scientific evidence that highlights their detrimental effects on human health, the environment, and the economy $[4,5]$. Moreover, their effectiveness has been affected by the appearance of resistant strains [6]. In this context, the biological control of diseases using microbial agents has advantages 
over chemical fungicides, given the availability of agents such as fungi, yeasts, and bacteria [2] and their safety and decreased probability of producing resistant strains.

In recent years, world markets have shown a growing tendency towards the use of biological control agents as an alternative to chemically synthesized pesticides [7]. Many microorganisms are currently being used as biopesticides because they offer a series of additional benefits over and above their objective function [8]. Entomopathogenic fungi stand out in this group and have been extensively studied for their effects as epiphytes for use in pest control and, on a smaller scale, against plant diseases $[9,10]$. However, in the last few years, there has been also a growing interest to study them as endophytes.

Endophytic fungi are defined as microorganisms that spend most or all of their lifecycle colonizing host plant tissues without causing any apparent damage to the host [11]. They are associated with the majority of plants, found naturally in the ecosystem, and considered an extremely important partner for plant development [12,13]. These microorganisms have been of interest in recent years because of the beneficial characteristics they confer to their hosts [14]. Some of these benefits are plant growth promotion, inhibition of pathogenic organisms, removal of soil contaminants, and increased tolerance to extreme temperature, water availability, and salinity conditions [15-17], all of which are important features for future agrifood production.

Several studies have demonstrated that endophytic fungi can protect host plants against pathogens and herbivores [18-22]. The host plant receives multiple benefits from the interaction with the endophyte in exchange for carbon-based resources [23]. Endophytes can remain in plant tissues for long periods of their lifecycle, thus protecting them from pathogen attacks as well as potential environmental changes that could threaten their survival and biocontrol efficiency [24]. They can establish interspecific interactions, and the protection against pathogen attack is produced by direct mechanisms, such as competition, parasitism, and antibiosis (production of primary and secondary metabolites, enzymes, or volatile compounds), and indirect mechanisms, such as induction of resistance [18,25].

In the present study, we used native strains of the entomopathogenic fungus Beauveria bassiana to determine its ability to endophytically colonize tomato and chili pepper plants. We also investigated if its presence inside the plants enables the mitigation of the negative effects caused by $B$. cinerea.

\section{Materials and Methods}

\subsection{Source of Fungal Strains and Seed}

Native strains of $B$. bassiana were used in the assays, isolated by the methodology described by France et al. [26], and identified by morphological and molecular methods. Botrytis cinerea strains isolated from tomato were also used. All strains were obtained from the Chilean Collection of Microbial Genetic Resources (CChRGM) (Table 1). Seeds of tomato var. Limachino-INIA traditional cultivar and chili pepper STa_01 used in this study, were obtained from the Sweet Saten Company.

\subsection{Surface Seed Disinfection}

Seeds were disinfected according to the protocol adapted from Ownley et al. [21] and Griffin [20]. Seeds were submerged in a 95\% ethanol solution for $1 \mathrm{~min}$ and then in $1.5 \% \mathrm{NaOCl}$ for $3 \mathrm{~min}$. They were washed three times for $1 \mathrm{~min}$ in sterile distilled water. Seeds were dried at room temperature on sterile absorbent paper for $3 \mathrm{~h}$ in a biosecurity cabinet and then used in all the assays involving plants. To test seed disinfection, a water sample from the third wash was taken with a bacteriological loop and streaked onto a Petri dish with potato dextrose agar (PDA) medium. On another dish with the same medium, the surface of one of the disinfected seeds was printed to rule out epiphytic colonization. 
Table 1. Fungal strains used in this study.

\begin{tabular}{cccc}
\hline Code Strain * & Species & Collection Location & Origin \\
\hline RGM 393 & Beauveria bassiana & Robinson Crusoe, Valparaíso Region, Chile. & Native forest soil \\
RGM 461 & Beauveria bassiana & Cañete, Biobío Region, Chile. & Natural pasture soil \\
RGM 547 & Beauveria bassiana & Santa Bárbara, Biobío Region, Chile. & Natural pasture soil \\
RGM 557 & Beauveria bassiana & Los Lagos, Los Lagos Region, Chile. & Natural pasture soil \\
RGM 565 & Beauveria bassiana & Portezuelo, Biobío Region, Chile. & Natural pasture soil \\
RGM 570 & Beauveria bassiana & Molina, Maule Region, Chile. & Arable soil, Vitis vinifera fruit crop \\
RGM 632 & Beauveria bassiana & Pencahue, Maule Region, Chile. & Natural pasture soil \\
RGM 644 & Beauveria bassiana & Icalma, La Araucanía Region, Chile. & Natural pasture soil \\
RGM 657 & Beauveria bassiana & Puerto Ibañez, Aysén del General Carlos Ibáñez & Natural pasture soil \\
& del Campo Region, Chile. & Natural pasture soil \\
RGM 731 & Beauveria bassiana & Río Cisnes, Aysén del General Carlos Ibáñez & Tomato plant \\
RGM 2519 & Botrytis cinerea & Colín, Maule Region, Chile & Tegion, Chile. \\
\hline
\end{tabular}

* Accession number of microorganisms from the Chilean Collection of Microbial Genetic Resources-CChRGM.

\subsection{Plant Inoculation with B. bassiana Strains and Endophytic Colonization}

Single conidia were inoculated on Petri dishes with $100 \%$ potato dextrose agar (PDA, Difco ${ }^{\mathrm{TM}}$ ) and $150 \mathrm{mg} \mathrm{L}^{-1}$ chloramphenicol. The dishes were incubated in the dark at $25 \pm 2{ }^{\circ} \mathrm{C}$ for 10 days. Conidia were harvested, and their viability was determined according to the methodology described by Moore et al. [27]. They were suspended in test tubes with $10 \mathrm{~mL}$ sterile distilled water and $0.01 \%(\mathrm{v} / \mathrm{v})$ Tween

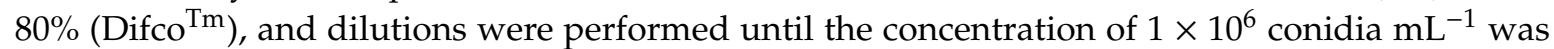
reached. In the case of the $B$. cinerea pathogen, it was used at concentrations of $1 \times 10^{5}$ conidia $\mathrm{mL}^{-1}$. The concentration of conidia was determined with a Neubauer counting chamber (BOECO, Germany), and the same inoculum was used for all the experiments.

Conidia suspension was inoculated in $100 \mathrm{~mL}$ test tubes containing $15 \mathrm{~mL}$ PDA [20]. One test tube was left without fungal inocula, as a control. Test tubes were incubated in the dark at $25 \pm 2{ }^{\circ} \mathrm{C}$ for 4 days. Once the apparent growth of the fungus in each tube was observed, $20 \mathrm{~mL}$ of the substrate was added, which consisted of a mixture of perlite, peat, compost, and vermiculite (2:2:2:1) sterilized twice in an autoclave at $120^{\circ} \mathrm{C}$ and $115 \mathrm{psi}$ for $1 \mathrm{~h}$. Controls were incubated at $25 \pm 2{ }^{\circ} \mathrm{C}$ for 5 days in the dark. Two seeds were sown in each test tube, and after emergence, one plant per tube was left. The tubes were incubated for 30 days in growth chambers at $25 \pm 2{ }^{\circ} \mathrm{C}$ with $12 \mathrm{~h} / 12 \mathrm{~h}$ light/darkness photoperiod and arranged in a randomized design with six replicates.

\subsection{Assessment of Endophytic Colonization}

To assess the endophytic colonization of B. bassiana strains, plants were extracted from the tubes and washed with tap water, and cuts were made to separate roots, stems, and leaves $(n=5)$. Each tissue was disinfected with $70 \%$ ethanol for $2 \mathrm{~min}$ and $1.5 \% \mathrm{NaOCl}$ for $5 \mathrm{~min}$ and rinsed three times for 1 min with sterile distilled water. Then they were left to dry on sterile absorbent paper, a modification of Resquín-Moreno et al. [28]. To control disinfection, the same procedure used to test the seeds was conducted. Once disinfection was accomplished, 10 subsamples were cut from each plant part (roots, stem, and leaves), resulting in a total of 30 pieces per plant. Root and stem samples were $10 \mathrm{~mm}$ long, whereas leaves were cut in $6 \mathrm{~mm}$ discs. The cuttings were distributed in Petri dishes with Noble agar (Difco ${ }^{\mathrm{TM}}$ ) medium plus chloramphenicol and incubated in the dark at $25 \pm 2{ }^{\circ} \mathrm{C}$ for 30 days. After the incubation, the pieces were evaluated by the presence of fungus growing from the border of the tissues, and the result obtained was the percentage of endophytic colonization (PEC). Strains that exhibited no endophytic colonization were discarded for use in the following evaluations.

\subsection{Morphological and Molecular Identification of Reisolate Strain}

Agar samples $\left(1 \mathrm{~cm}^{2}\right)$ with mycelia growing from inside the leaves inoculated with the endophyte were placed on a slide. Fungal structures were observed under an optical microscope with $40 \times$ magnification and were identified through taxonomic keys [29]. For molecular identification, 
samples were taken from mycelia coming out of the plant tissues and sown in the PDA medium. The polymerase chain reaction (PCR) method was used with specific markers for B. bassiana P1 (5'AAGCTTCGACATGGTCTG) and P3 (5'GGAGGTGGTGAGGTTCTGTT) according to the methodology described by Hegedus and Khachatourians [30]. Amplification products were separated in agarose gel and observed under ultraviolet light. Once the identity was confirmed, monoxenic samples were taken from the reisolation of each strain and used as the inoculum in the next assays.

\subsection{In Vitro Antifungal Activity of Endophytic B. bassiana}

Mycelium discs (3 days, $5 \mathrm{~mm}$ diameter) from pure B. bassiana cultures obtained from plant tissues were placed $1.5 \mathrm{~cm}$ from the edge of a $9 \mathrm{~cm}$ Petri dish containing the PDA medium $(20 \mathrm{~mL})$. After $2 \mathrm{~d}$, discs with $B$. cinerea pathogen ( 3 days, $5 \mathrm{~mm}$ diameter) were equidistantly placed opposite to the endophyte and incubated in the dark at $25 \pm 2{ }^{\circ} \mathrm{C}$ for $10 \mathrm{~d}$. Six replicates were included per treatment and were placed in a completely randomized design. At the same time, control dishes containing only the pathogen were prepared [31]. When the pathogen colonized the whole Petri dish, the percentage of radial growth inhibition of the pathogen (PRGIP) was determined by Formula (1). The radii of the colonies were measured $(\mathrm{mm})$ in each of the treatments using a digital caliper.

$$
\text { PRGIP : [(R1-R2)/R1] × } 100
$$

where R1 is the radius of the pathogen colony growing alone ( $\mathrm{mm}$ ) and $\mathrm{R} 2$ is the radius of the pathogen colony competing against the endophyte (mm).

\subsection{Evaluation of Antifungal Activity in the Host Plant}

Previously disinfected tomato and chili pepper seeds were sown in individual $300 \mathrm{~mL}$ pots on a substrate consisting of a mixture of perlite, peat, compost, and vermiculite (2:2:2:1) sterilized twice in an autoclave at $120^{\circ} \mathrm{C}$ and 115 psi for $1 \mathrm{~h}$. Pots were left in growth chambers (at $25 \pm 2{ }^{\circ} \mathrm{C}, 65 \%$ relative humidity, and $12 \mathrm{~h} / 12 \mathrm{~h}$ light/darkness photoperiod) for 30 and 60 days for tomato and chili pepper, respectively. Plants were observed and watered with $3 \mathrm{~mL}$ of sterile distilled water every 5 days. Plants with 4-5 true leaves were inoculated with the endophyte by drenching the substrate with a solution of $5 \mathrm{~mL}$ sterile distilled water and $2 \mathrm{~mL}$ of the conidial solution $\left(1 \times 10^{6}\right.$ conidia $\left.\mathrm{mL}^{-1}\right)$. The five strains that exhibited the best antifungal performance in the in vitro tests were selected. Pots were covered at their bases with aluminum foil to prevent cross-contamination of the endophyte and maintained for another 10 days in the growth chambers under the same conditions previously described. A conidial solution of the pathogen $\left(1 \times 10^{5}\right.$ conidia $\left.\mathrm{mL}^{-1}\right)$ was then prepared, using a modification of the method by Martin-Hernández et al. [32], and applied 14 days after the endophytes as a foliar spray on tomato and chili pepper leaves (of the same age). For the analyses, three and two leaves located in the middle part of the chili pepper (eight weeks) and tomato plant (six weeks), respectively, were selected. The treatments were arranged in a randomized design, with five replications for each strain.

The disease incidence in both hosts was evaluated 10 days postinoculation of the pathogen [33] by calculating the percentage of the surface affected by the pathogen (PSAP) by Formula (2). The total area (TA) and affected area (AA) per leaf were obtained with the ImageJ, an open-source image processing software [34]. The software allows quantitatively determining the leaf area covered by sporulation, damage, or chlorotic and necrotic symptoms. For both species, the assay was conducted two times under the same conditions.

$$
\text { PSAP : }(S 2 / S 1) \times 100
$$

where S1 is the total leaf surface, and S2 is the leaf surface affected by the pathogen. 


\subsection{Statistical Analyses}

In all cases, a completely randomized design was used. Prior to the statistical analyses, data were used to determine the normality and homogeneity of the variance. The results were used to perform variance analyses and the means were compared with Fisher's least significant difference (F-LSD) test $(p<0.05)$ with the software InfoStat Version 2011 [35].

\section{Results}

\subsection{Endophytic Colonization of B. bassiana Strains in Tomato and Chili Pepper Plants}

The ten evaluated strains of B. bassiana colonized internally the different parts of the tomato plants, while eight strains colonized the chili pepper plants. White mycelium growing from the different plant tissues was observed with an optical microscope (Figure 1). Structures such as hyphae, conidiophore, and conidia of B. bassiana were observed in the different treatments and confirmed by morphology and subsequent molecular analyses. The specific molecular markers gave positive amplification in all of the evaluated strains; consequently, the endophyte identity was confirmed as B. bassiana.

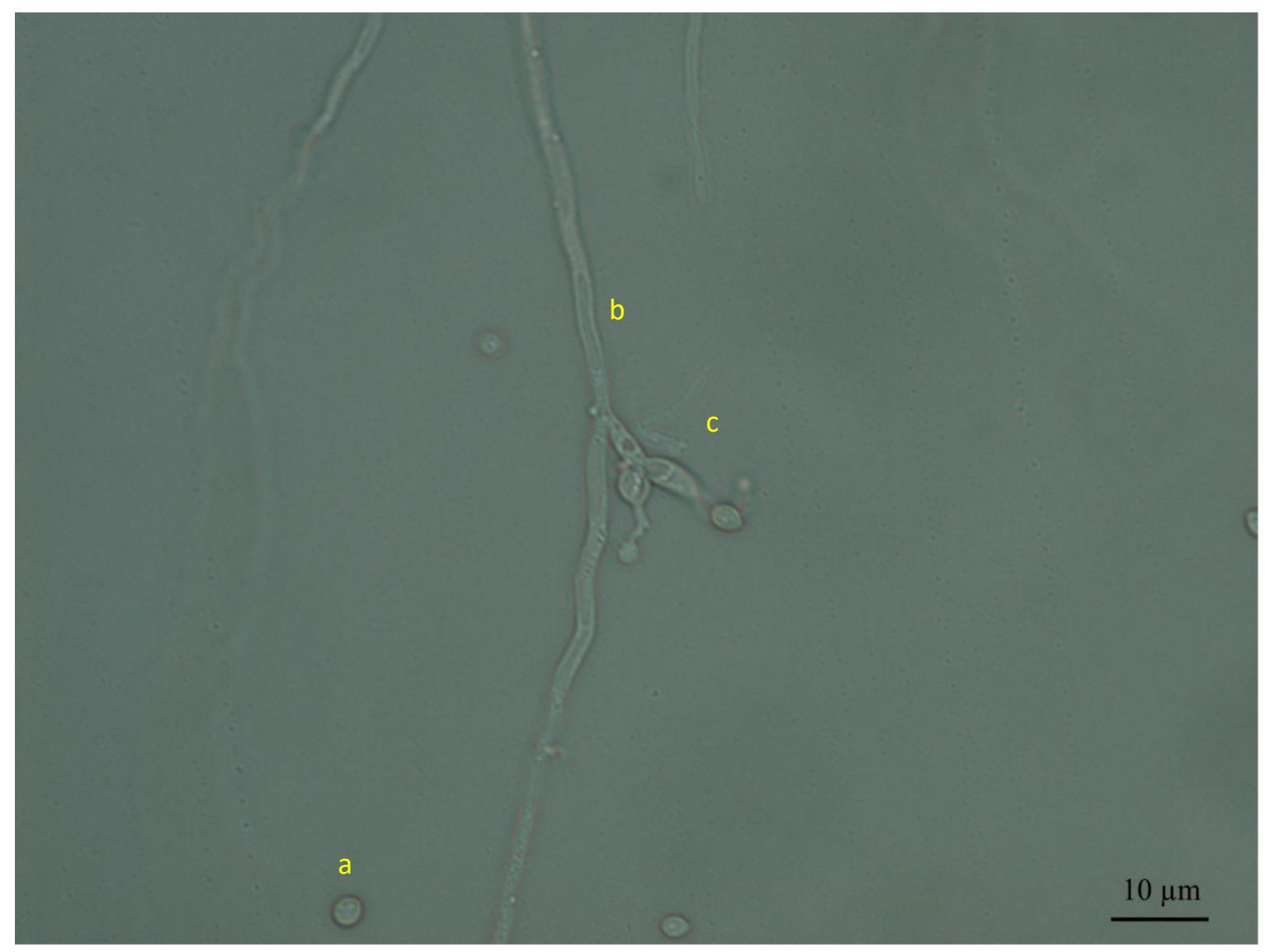

Figure 1. Morphological characteristics of endophyte Beauveria bassiana (RGM 644) on Noble agar $(100 \times)$. (a) Conidia, (b) conidiogenous cells, and (c) hyphae.

By using both disinfection control methods (water and tissue printing), epiphytic colonization could not be detected, and therefore, all the observed mycelium growth came from the internal tissues. No B. bassiana was reisolated from the different tissue plants used as a control without fungal inoculation (Table 2). 
Table 2. Endophytic colonization (\%) of Beauveria bassiana in tomato and chili pepper $(n=5)$

\begin{tabular}{|c|c|c|c|c|c|c|c|c|c|c|c|c|}
\hline \multirow{2}{*}{ Species } & \multirow{2}{*}{ Plant Part } & \multicolumn{11}{|c|}{ Treatments } \\
\hline & & RGM 393 & RGM 461 & RGM 547 & RGM 557 & RGM 565 & RGM 570 & RGM 632 & RGM 644 & RGM 657 & RGM 731 & Control $^{1}$ \\
\hline \multirow{3}{*}{ Chili pepper } & Leaves & $0^{2} \pm 0.0^{3} \mathrm{~d}^{4}$ & $0 \pm 0.0 \mathrm{~d}$ & $68 \pm 13.6 a$ & $28 \pm 13.6 \mathrm{bc}$ & $36 \pm 16.0 \mathrm{~b}$ & $36 \pm 7.5 b$ & $10 \pm 3,2 \mathrm{~cd}$ & $36 \pm 7.5 b$ & $32 \pm 8.0 \mathrm{bc}$ & $52 \pm 8.0 \mathrm{ab}$ & $0 \pm 0.0 \mathrm{~d}$ \\
\hline & & $0 \pm 0.0 \mathrm{~b}$ & $.0 \mathrm{~b}$ & & $12 \pm 2 \mathrm{a}$ & $14 \pm 2.5 \mathrm{a}$ & $14 \pm 2.5 \mathrm{a}$ & & $14 \pm 4.0 \mathrm{a}$ & $2.5 \mathrm{a}$ & $\pm 2.5 \mathrm{a}$ & $0.0 \mathrm{~b}$ \\
\hline & Roots & $0 \pm 0.0 \mathrm{~d}$ & $0 \pm 0.0 \mathrm{~d}$ & $34 \pm 6.8 \mathrm{a}$ & $18 \pm 5.8 \mathrm{bc}$ & $18 \pm 8 \mathrm{bc}$ & $18 \pm 3.7 \mathrm{bc}$ & $10 \pm 3.2 \mathrm{~cd}$ & $16 \pm 5.1 \mathrm{bc}$ & $24 \pm 9.8 \mathrm{abc}$ & $28 \pm 3.7 \mathrm{ab}$ & $0 \pm 0.0 \mathrm{~d}$ \\
\hline \multirow{3}{*}{ Tomato } & Leaves & $10 \pm 6.3 \mathrm{ab}$ & $10 \pm 3.9 \mathrm{ab}$ & $34 \pm 17.2 \mathrm{ab}$ & $48 \pm 23.1 \mathrm{a}$ & $24 \pm 19.4 \mathrm{ab}$ & $22 \pm 11.8 \mathrm{ab}$ & $20 \pm 12.3 \mathrm{ab}$ & $24 \pm 19.4 \mathrm{ab}$ & $26 \pm 3.7 \mathrm{ab}$ & $18 \pm 8.0 \mathrm{ab}$ & $0 \pm 0.0 \mathrm{~b}$ \\
\hline & Stems & $12 \pm 8.0 \mathrm{abc}$ & $36 \pm 19.8 \mathrm{abc}$ & $44 \pm 21.1 \mathrm{ab}$ & $38 \pm 19.4 \mathrm{ab}$ & $36 \pm 16 . a b c$ & $46 \pm 6.9 \mathrm{a}$ & $12 \pm 8.0 \mathrm{abc}$ & $12 \pm 8.0 \mathrm{abc}$ & $8 \pm 5.8 \mathrm{bc}$ & $36 \pm 6.0 \mathrm{abc}$ & $0 \pm 0.0 \mathrm{~b}$ \\
\hline & Roots & $8 \pm 4.9 \mathrm{~b}$ & $18 \pm 11.9 \mathrm{ab}$ & $24 \pm 19.4 \mathrm{ab}$ & $46 \pm 22.3 a$ & $34 \pm 17.2 \mathrm{ab}$ & $16 \pm 5.1 \mathrm{ab}$ & $20 \pm 12.3 \mathrm{ab}$ & $28 \pm 18.6 \mathrm{ab}$ & $18 \pm 9.7 \mathrm{ab}$ & $8 \pm 4.9 \mathrm{~b}$ & $0 \pm 0.0 \mathrm{~b}$ \\
\hline
\end{tabular}

${ }^{1}$ Control represents plants without Beauveria bassiana applications. ${ }^{2}$ Mean values of endophytic (\%) colonization $(n=6) .{ }^{3}$ Standard error. ${ }^{4}$ Mean values of the same treatment followed by a different letter are significantly different according to Fisher's least significant difference (LSD) test $(p<0.05)$. 
In tomato, $100 \%$ of the evaluated strains exhibited some degree of endophytic colonization. Colonization fluctuated between $10 \%$ and $48 \%$ in the leaves and $8 \%$ and $46 \%$ in the stem and roots. Furthermore, $100 \%$ of the strains demonstrated a systemic mode of action, where the fungus inoculated in the roots was re-isolated from the leaves. The strain with the best performance, considering the sum of all plant tissue, was RGM 557 (50\%), while the strain RGM 393 had the worst performance (10\%) $(F=1.24 ; \mathrm{df}=10 ; p=0.29)$. For chili pepper, endophyte colonization fluctuated between $0-68 \%$ in the leaves, $0-14 \%$ in the stem, and $0-34 \%$ in the roots. Strains RGM 393 and RGM 461 exhibited no endophytic colonization ability. The strain with the best overall performance was RGM 547 with $35 \%$ (sum of all tissue plant colonized), and the worst performance $(F=14,76 ; \mathrm{df}=10 ; p<0.0001)$ among the strains that achieved some degree of colonization was RGM 632 with 7\%. The highest percentages of endophytic colonization between the different tissues of tomato plant were in stems. In the chili pepper plant, the highest percentages were in the leaves.

\subsection{In Vitro Growth Inhibition of the Pathogen}

The monoxenic culture of the pathogen was able to totally colonize the Petri dish after 7 days in a $75 \mathrm{~mm}$ radius. When the advance of the pathogen against the endophytic strains was measured, all the cases showed a level of radial growth inhibition of the pathogen, and the PRGIP fluctuated between $30 \%$ and $39 \%$. The pathogen was only able to grow $45 \mathrm{~mm}$ against strain RGM $644(F=2.13 ; \mathrm{df}=7$; $p=0.062)$, while the greatest advance $(53 \mathrm{~mm}$ ) was against the strain RGM 657 (Figure 2).

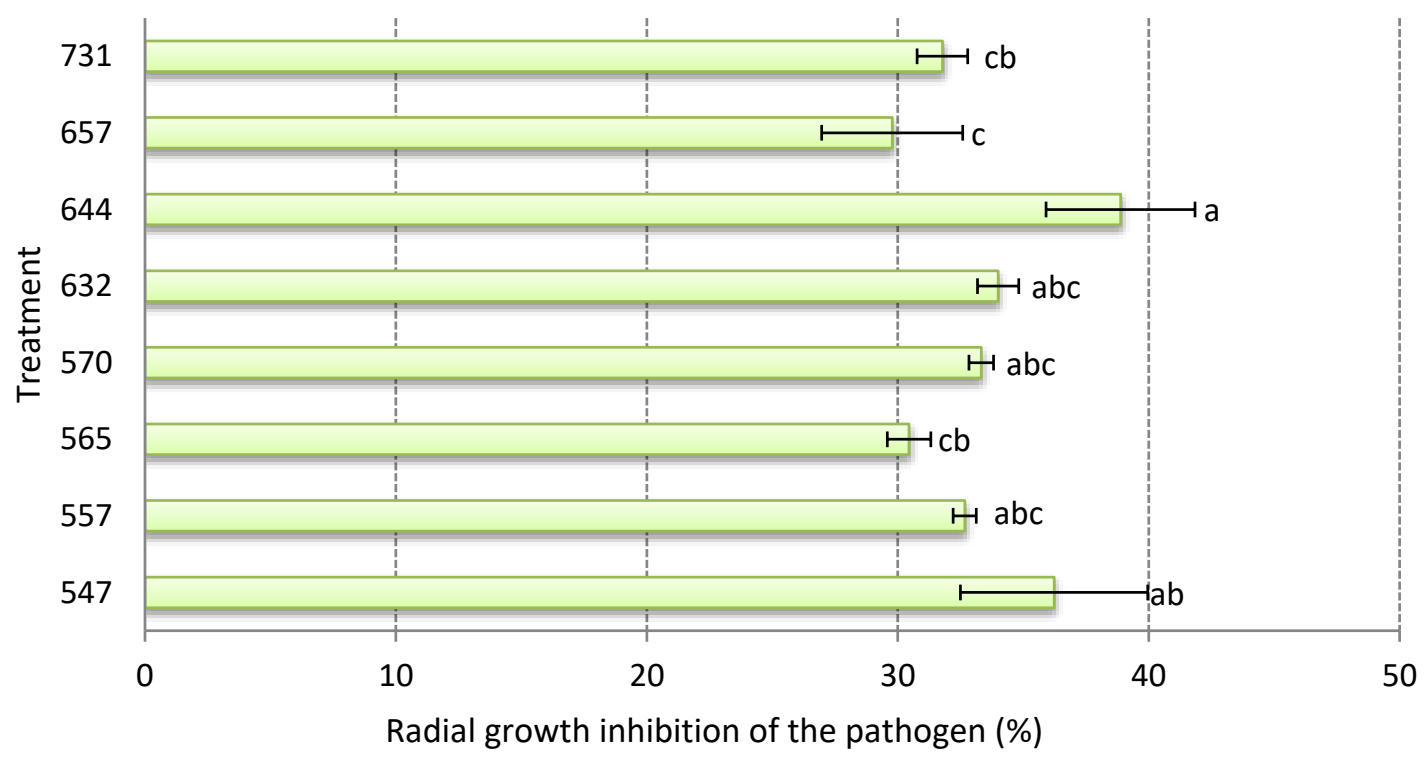

Figure 2. Radial inhibition growth of Botrytis cinerea (\%) against strains of endophytic Beauveria bassiana at 7 days $(n=6)$. Data represent the mean \pm standard error. Different letters over the bars represent significant differences among the treatments according to the Fisher's LSD test $(p<0.05)$.

It was observed that some strains did not allow mycelia to achieve the density and tonality found in the control plate. Moreover, in strains with the best performance in terms of PGIP, almost no sclerotia were detected (Figure 3).

\subsection{Antifungal Activity in the Host Plant}

The PSAP in chili pepper leaves was noteworthy as being lower in plants $(F=11.46$; $\mathrm{df}=6$; $p<0.0001$ ) inoculated with endophytes compared to plants only inoculated with the pathogen. The plants inoculated with endophytes ranged from $2 \%$ to $18 \%$ of PSAP, with the lowest for RGM 547 strain and the highest for RGM 557. Meanwhile, treatment only with the pathogen exhibited early symptoms of the disease (during the first week of inoculation) with a PSAP of 63\%, while some symptoms were 
observed after the second week in plants with endophytes (all endophyte treatment). Leaves of plants that were not inoculated with the pathogen showed no symptoms of the disease (Figure 4).

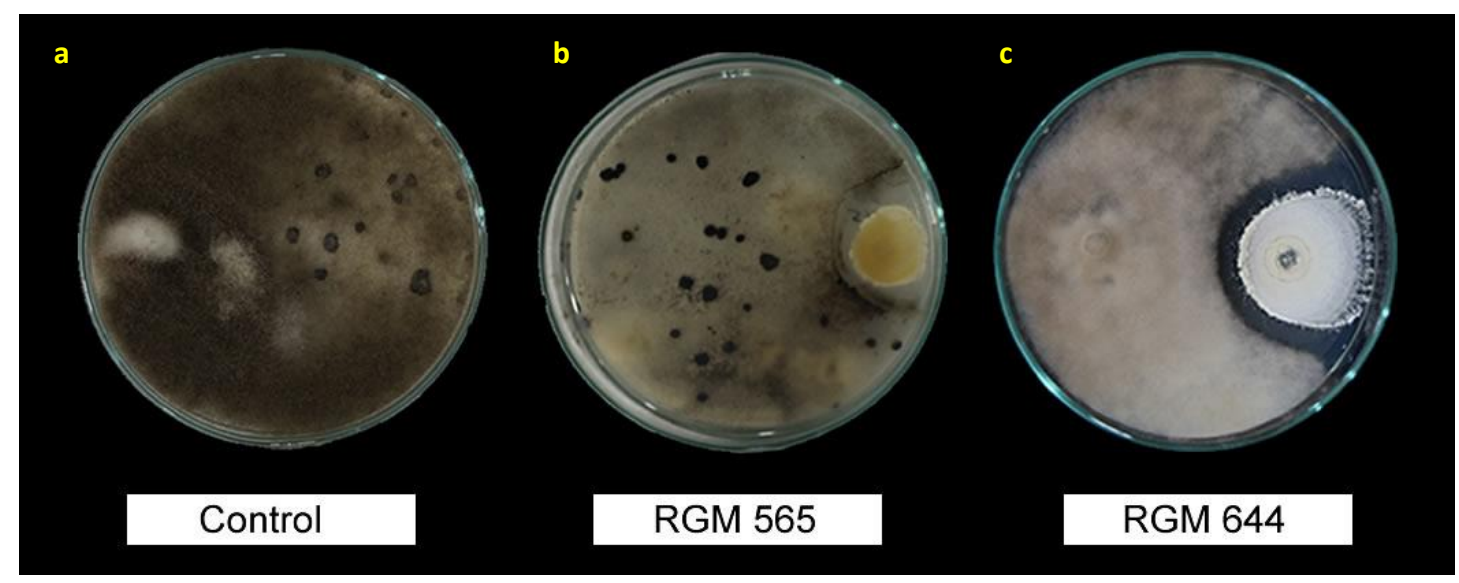

Figure 3. Dual cultures of Botrytis cinerea against different endophytic strains of Beauveria bassiana. (a) Botrytis cinerea (control) $7 \mathrm{~d}$ after inoculation, (b) pathogen against endophytic strains RGM 565 and

(c) RGM 644, showing different mycelia density and inhibition of sclerotia.
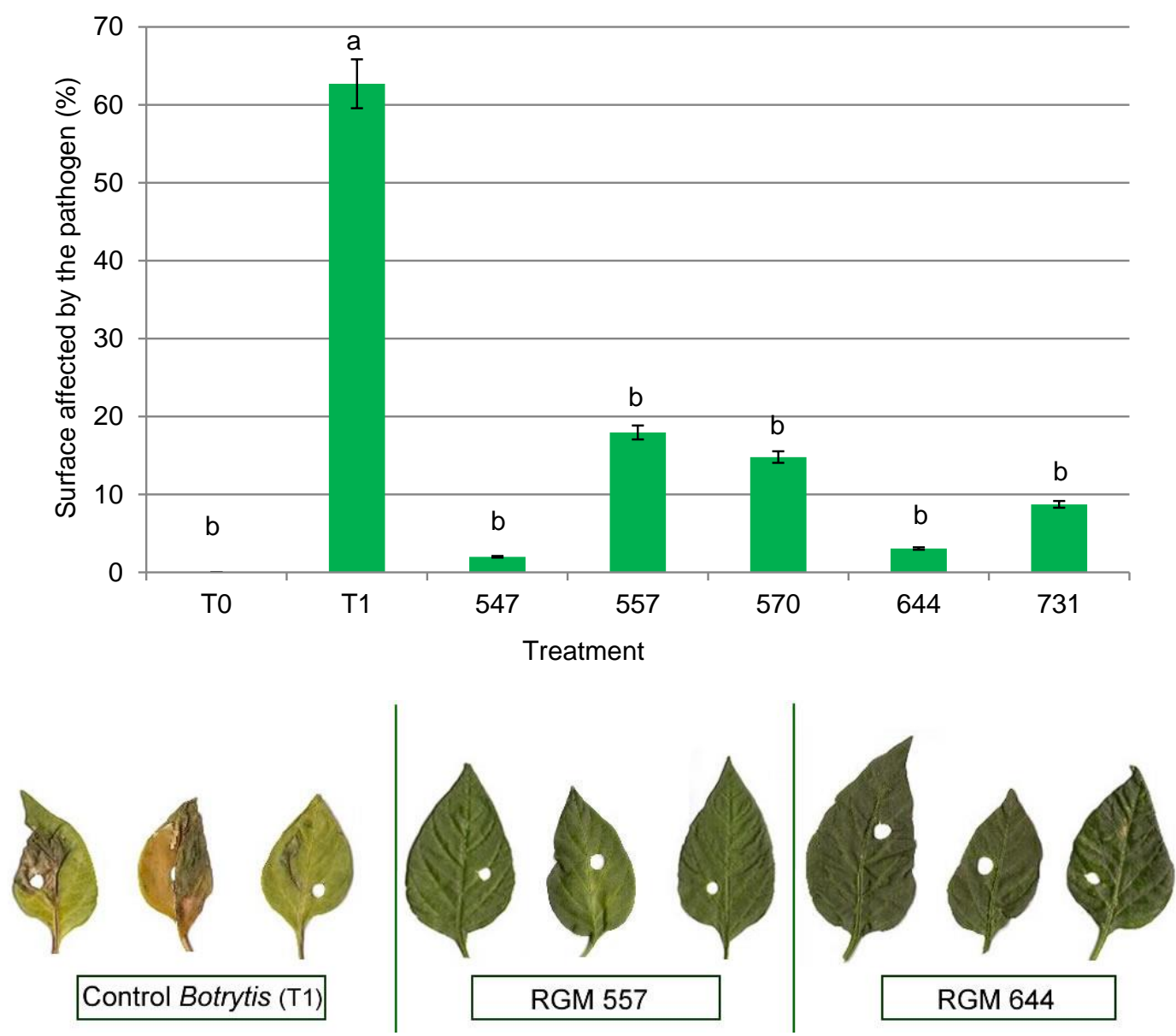

Figure 4. Surface affected by the pathogen $\left(\mathrm{cm}^{2}\right)$ in chili pepper leaves 10 days postinoculation $(n=5)$. The leaves of plants not inoculated with Botrytis cinerea (T0) were asymptomatic. The leaves with endophytic strains showed a low level of symptoms (RGM 547, RGM 557, RGM 570, RGM 644, and RGM 731), while the leaves of plants inoculated with B. cinerea RGM 2519 (T1) exhibited chlorotic and necrotic spots. Values are expressed as means \pm standard error. Means with different letters are significantly different at $p<0.05$ by Fisher's LSD test. 
In the case of tomato, leaves of plants inoculated with the pathogen had the highest PSAP $(40.0 \%)$, which was notably higher $(F=4.51 ; \mathrm{df}=6 ; p=0.0007)$ than the percentages obtained for plants inoculated with endophytes. This percentage is similar to the result obtained in chili pepper. The range of PSAP for plants with endophytes was $2.5 \%$ to $16.9 \%$, and significant differences existed among strains. The strains with the lowest percentage were RGM 644 and 731 , with values of $2.5 \%$ and $4.7 \%$, respectively. The strains with the highest pathogen incidence were RGM $557(16.9 \%)$ and 570 (15.9\%). Leaves of plants that were not inoculated with the pathogen exhibited no symptoms of the disease (Figure 5).
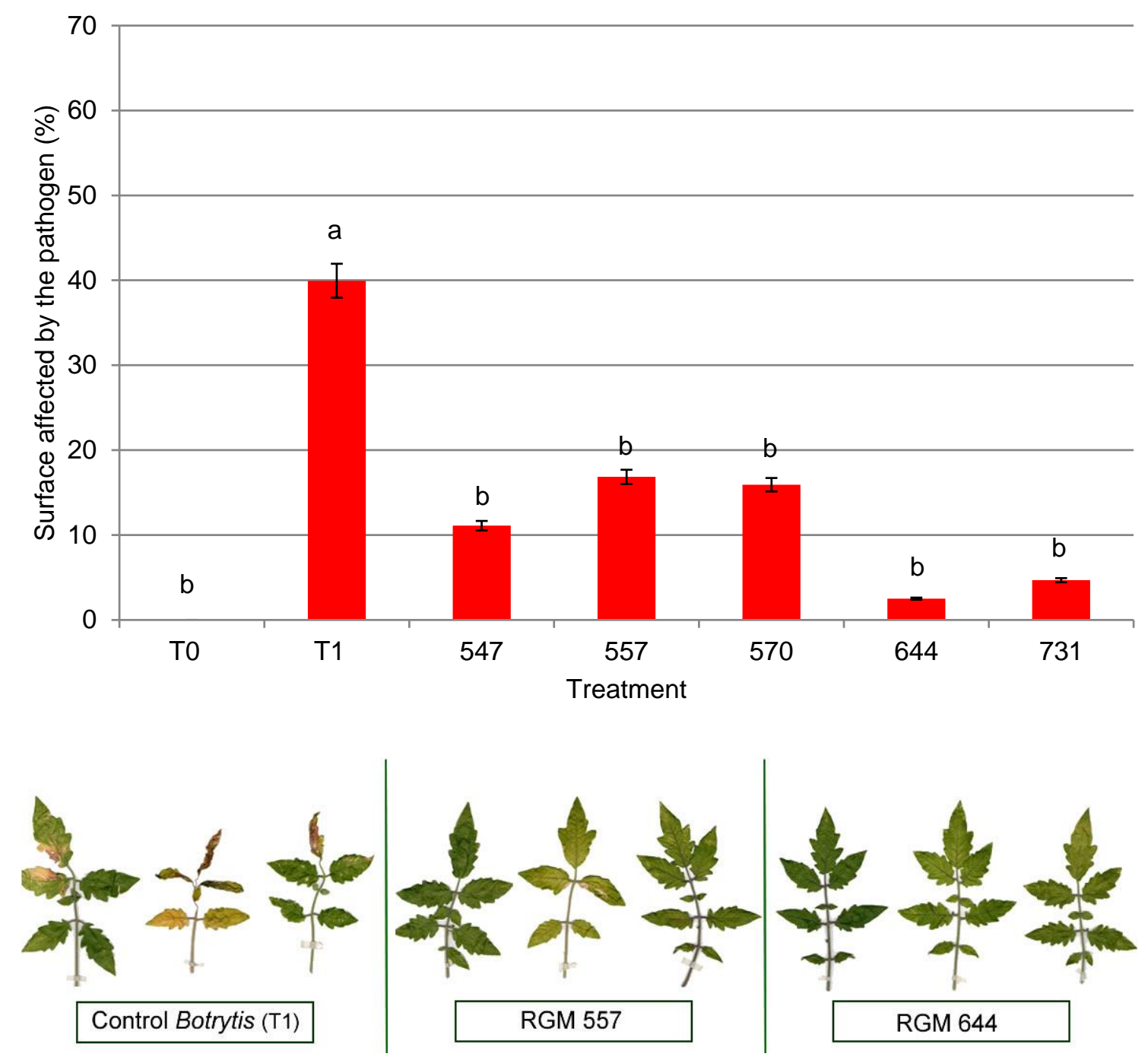

Figure 5. Surface affected by the pathogen $\left(\mathrm{cm}^{2}\right)$ in tomato leaves at 10 days postinoculation $(n=5)$. The leaves of plants not inoculated with Botrytis cinerea (T0) were asymptomatic. The leaves with endophytic strains showed a low level of symptoms (RGM 547, RGM 557, RGM 570, RGM 644, and RGM 731), while the leaves of plants inoculated with B. cinerea RGM 2519 (T1) exhibited chlorotic and necrotic spots. Values are expressed as means \pm standard error. Means with different letters are significantly different at $p<0.05$ by Fisher's LSD test.

\section{Discussion}

\subsection{Endophytic Colonization of Beauveria bassiana Strains}

The present study reports on the colonization of B. bassiana in tomato and chili pepper as endophytes. Every evaluated strain was able to endophytically colonize tomato plants; these results 
concur with those shown by other studies in tomato [20,21,36]. As for chili pepper, $80 \%$ of the strains endophytically colonized the plants. Studies conducted by Paul et al. [37] reveal an assorted diversity of endophytic microorganisms in chili pepper, including some entomopathogens as Paecilomyces, Cordyceps, Cladosporium, and Penicillium; however, the authors do not report the natural presence of B. bassiana. Recent studies on chili and sweet pepper demonstrated the endophytic colonization of B. bassiana, and these are some examples of the limited numbers of reports about the colonization on this species $[38,39]$.

The results of endophytic colonization in tomato leaves (10-48\%) in this study were lower than those presented by Klieber and Reineke [40], who obtained the highest colonization (60\%). This may be due to several factors, such as the disinfection technique, which could kill the endophyte [36], the inoculation techniques [21], the type of leaf used for sampling (tissue age and location in the plant), the time between inoculation and reisolation [40], and the plant's endophytic microbial community because actinobacteria and yeasts were also found in the reisolation. Several studies have provided evidence of the endophytic colonization of B. bassiana in plants inoculated by different methods through the seeds, leaves, and roots [21,41-43]. This fungus has been reported as a facultative endophyte of several plants [44], suggesting that B. bassiana is not a specific endophyte for a plant species or particular cultivar. This characteristic can be related to the specificity exhibited by entomopathogenic fungi with the host insect; this can be very limited in the case of obligate pathogens or very broad in the case of facultative pathogens [45].

It was observed that B. bassiana showed a systemic colonization pattern for both plant species, and thus, the fungus was reisolated from the roots, stem, and leaves. Previous studies conducted with other Solanaceae have also demonstrated a systemic colonization pattern for these fungi $[39,43,46]$. Behie et al. [47], in Phaseolus vulgaris, demonstrated that B. bassiana is able to colonize plant tissues on and below the soil, while endophytes of the genus Metarhizium prefer to colonize the roots. This colonization pattern is very interesting from the viewpoint of the development of biocontrollers because it would allow access to places in the plant that most chemical products cannot reach.

The important colonization levels obtained for both species in the present assay can be related to the evolution of these fungi over time. Barelli et al. [48] suggest that some entomopathogenic fungi evolved from fungi related to plants (symbionts) and that the pathogenicity in insects is part of a more recent adaptive process. In other words, these fungi were endophytes at first and then were able to become independent of the plants and survive as insect pathogens. The same authors also propose that these fungi have never left their symbiotic relationship with the plant and that pathogenicity towards insects could be a strategy by which the endophytes have access to nitrogen sources in exchange for carbohydrates provided by the plant; this mechanism was reported by Herre et al. [23] and Behie [49].

Although there is an important number of reports about the endophytic colonization of B. bassiana and its action as a biological control agent, most of them have been carried out under controlled conditions, like the present study. However, field conditions could affect its action [50]. Beauveria bassiana is classified as saprophytic and exhibits poor competition in the soil [51,52]. Therefore, soil inoculations could be inefficient because of the poor survival of the endophyte when encountering more competitive microbiota, hindering its arrival to the roots and limiting its endophytic colonization [53]. On the other hand, in foliar applications, these fungi spend a significant amount of time on the leaf surface, and their germination could be affected by radiation, temperature, and humidity conditions [54].

\subsection{In Vitro Growth Inhibition of the Pathogen Botrytis cinerea}

The important levels of pathogen inhibition by these nine strains of B. bassiana could be due to the ability of these fungi to produce a great variety of bioactive metabolites, which have antimicrobial properties $[55,56]$. Oosporein, beauvericin, bassianolide, bassianin, beauveriolide, bassiacridin, and cyclosporine are highlighted among the metabolites produced by this fungus [57-60], and of these, oosporein and beauvericin have antifungal activity [61,62]. Studies conducted by Feng et al. [63] determined that the genome of B. bassiana has at least 45 different groups of secondary metabolite 
biosynthesis gene clusters. The dissemination of these compounds in the medium affects the growth of pathogenic fungi. Other in vitro evaluations have also demonstrated the antifungal effect of the endophyte against pathogens such as Botrytis cinerea, Cladosporium herbarum [64], Fusarium spp. [64,65], Gaeumannomyces graminis var. tritici [66], and Rhizoctonia solani [67]. Antibiosis and/or competition are highlighted among the mechanisms used by the endophyte to inhibit pathogen growth. Mycoparasitism was not detected when observing the advance zone under the microscope; this suggests that the evaluated strains have no ability to parasitize $B$. cinerea hyphae.

\subsection{Antifungal Activity in the Host Plant against Botrytis cinerea}

The results obtained in this study suggest that the action of B. bassiana as an endophyte increase the plant's ability to resist the attack of pathogens such as B. cinerea. Thus, the endophyte exhibits a relevant antifungal activity against $B$. cinerea in both tomato and chili pepper. Beauveria bassiana was applied to and subsequently colonized roots, moving up to the stem, presumably through the vascular system [55], and reaching the leaves where the pathogen was inoculated. Several plants inoculated with different strains were asymptomatic, while the control was affected, and PSAP was greater than $39 \%$. A growing number of studies provide evidence of the protective action that B. bassiana confers on different pathogens [21,67-70]; the present study is the first report that demonstrates the protective effect of B. bassiana endophyte against B. cinerea on chili pepper and tomato.

The lowest PSAP obtained in chili pepper and tomato leaves could be the result of a direct or indirect effect of the endophyte in the plant. Direct effects would occur when the endophyte is able to enter through the roots, move through the vascular system until reaching the leaf tissues, and compete for space and food with the pathogen, reducing its colonizing ability [67]. Another possibility could be when pathogen hyphae enter the leaves and are parasitized by the endophyte hyphae (mycoparasitism), which weaken and decrease their damage potential [21].

The indirect effect could firstly be due to the action of secondary metabolites, as mentioned for dual cultures that could act in distant plant tissues from which they are produced. There would be enzymes degrading the cell wall within these metabolites, which is an important mechanism involved in controlling phytopathogenic fungi [70]. Secondly, indirect action could occur by activating the systemic resistance in the plant, an action mechanism used by the endophyte $B$. bassiana against zucchini yellow mosaic virus in pumpkin and against Xanthomonas axonopodis pv. malvacearum in cotton, as reported by Jaber and Salem [71] and Ownley et al. [21], respectively. According to Vega et al. [68] and Ownley et al. [16], the antifungal action exhibited by endophytes could be due to a mixture of the previously mentioned mechanisms rather than to the action of a single mechanism.

\section{Conclusions}

The results of the present study provide evidence of the potential exhibited by endophytic strains of Beauveria bassiana to control Botrytis cinerea in chili pepper and tomato; eventually, they could be used to control diseases in other species of the Solanaceae family. Future research should focus on conducting assays under field conditions because of the possible effects of the environment on soil and leaf inoculations with the endophyte. It is also necessary to perform complete sequencing of the strains, aimed at identifying possible genetic relationships with their antifungal activity.

The use of endophytic fungi could overcome some of the challenges faced in controlling plant diseases such as chemical fungicide toxicity, the appearance of resistance of some pathogens, and food safety. The studied isolates represent excellent candidates for the development of biocontrol tools to control not only insects but also pathogens. They could be used preventively within an integrated management strategy due to the diversity of mechanisms by which they could act against the attack of different pathogens. However, as Beauveria bassiana produces a considerable amount of secondary metabolites that could act as mycotoxins, it is necessary to increase the number of studies to determine the potential damage that mycotoxins of this fungus could cause in health to people and animals in its action as endophytes. 
Author Contributions: Conceptualization: A.F.I., G.S.A., M.G.G. and L.B.-B.; methodology, J.C.-F., J.O.C. and L.B.-B.; formal analysis, L.B.-B.; investigation L.B.-B., J.C.-F. and J.O.C.; manuscript writing, editing, and review: A.F.I., G.S.A., M.G.G., J.F.C. and L.B.-B.; supervision and project administration: L.B.-B. All authors have read and agreed to the published version of the manuscript.

Funding: This research was funded by the Fund of Innovation for the Competitiveness of Maule Region Chile, through the project: Native Endophytes for the Control of Pests and Diseases.

Acknowledgments: The authors would like to thank everyone who works in the Genetic Resources Network of INIA and especially to the colleagues of Banco de Recursos Genéticos Microbianos.

Conflicts of Interest: The authors declare no conflict of interest.

\section{References}

1. Punja, Z.K.; Rodriguez, G.; Tirajoh, A. Effects of Bacillus Subtilis strain QST 713 and storage temperatures on post-harvest disease development on greenhouse tomatoes. Crop Prot. 2016, 84, 98-104. [CrossRef]

2. Williamson, B.; Tudzynski, B.; Tudzynski, P.; van Kan, J.A. Botrytis Cinerea: The cause of grey mould disease. Mol. Plant Pathol. 2007, 8, 561-580. [CrossRef] [PubMed]

3. Droby, S.; Lichter, A. Post-harvest Botrytis infection: Etiology, development and management. In Botrytis: Biology, Pathology and Control; Springer: Berlin/Heidelberg, Germany, 2007; pp. 349-367.

4. Carisse, O.; Tremblay, D.-M.; Jobin, T.; Walker, A.S. Disease decision support systems: Their impact on disease management and durability of fungicide effectiveness. Fungicides 2010, 177-200. [CrossRef]

5. Kaonga, C.C.; Chidya, R.C.G.; Kosamu, I.B.M.; Abdel-Dayem, S.M.; Mapoma, H.W.T.; Thole, B.; Mbewe, R.; Sakugawa, H. Trends in usage of selected fungicides in Japan between 1962 and 2014: A Review. Int. J. Environ. Sci. Technol. 2018, 15, 1801-1814. [CrossRef]

6. Leroux, P.; Gredt, M.; Leroch, M.; Walker, A.-S. Exploring mechanisms of resistance to respiratory inhibitors in field strains of Botrytis cinerea, the causal agent of gray mold. Appl. Environ. Microbiol. 2010, 76, 6615-6630. [CrossRef]

7. Bailey, K.L.; Boyetchko, S.M.; Längle, T. Social and economic drivers shaping the future of biological control: A canadian perspective on the factors affecting the development and use of microbial biopesticides. Biol. Control 2010, 52, 221-229. [CrossRef]

8. Glare, T.; Caradus, J.; Gelernter, W.; Jackson, T.; Keyhani, N.; Köhl, J.; Marrone, P.; Morin, L.; Stewart, A. Have Biopesticides come of age? Trends Biotechnol. 2012, 30, 250-258. [CrossRef]

9. Lozano-Tovar, M.D.; Ortiz-Urquiza, A.; Garrido-Jurado, I.; Trapero-Casas, A.; Quesada-Moraga, E. Assessment of entomopathogenic fungi and their extracts against a soil-dwelling pest and soil-borne pathogens of olive. Biol. Control 2013, 67, 409-420. [CrossRef]

10. Lozano-Tovar, M.D.; Garrido-Jurado, I.; Quesada-Moraga, E.; Raya-Ortega, M.C.; Trapero-Casas, A. Metarhizium brunneum and Beauveria Bassiana release secondary metabolites with antagonistic activity against Verticillium Dahliae and Phytophthora Megasperma olive pathogens. Crop Prot. 2017, 100, 186-195. [CrossRef]

11. Bascom-Slack, C.A.; Arnold, A.E.; Strobel, S.A. Student-directed discovery of the plant microbiome and its products. Science 2012, 338, 485-486. [CrossRef]

12. Hallmann, J.; Quadt-Hallmann, A.; Mahaffee, W.F.; Kloepper, J.W. Bacterial endophytes in agricultural crops. Can. J. Microbiol. 1997, 43, 895-914. [CrossRef]

13. Arnold, A.E.; Maynard, Z.; Gilbert, G.S.; Coley, P.D.; Kursar, T.A. Are tropical fungal endophytes hyperdiverse? Ecol. Lett. 2000, 3, 267-274. [CrossRef]

14. Aly, A.H.; Debbab, A.; Kjer, J.; Proksch, P. Fungal endophytes from higher plants: A prolific source of phytochemicals and other bioactive natural products. Fungal Divers. 2010, 41, 1-16. [CrossRef]

15. Quesada-Moraga, E.; Munoz-Ledesma, F.J.; Santiago-Alvarez, C. Systemic protection of Papaver Somniferum L. against Iraella Luteipes (Hymenoptera: Cynipidae) by an endophytic strain of Beauveria Bassiana (Ascomycota: Hypocreales). Environ. Entomol. 2009, 38, 723-730. [CrossRef] [PubMed]

16. Ownley, B.H.; Gwinn, K.D.; Vega, F.E. Endophytic fungal entomopathogens with activity against plant pathogens: Ecology and evolution. BioControl 2010, 55, 113-128. [CrossRef]

17. Kauppinen, M.; Saikkonen, K.; Helander, M.; Pirttilä, A.M.; Wäli, P.R. Epichloë grass endophytes in sustainable agriculture. Nat. Plants 2016, 2, 15224. [CrossRef] 
18. Arnold, A.E.; Mejía, L.C.; Kyllo, D.; Rojas, E.I.; Maynard, Z.; Robbins, N.; Herre, E.A. Fungal endophytes limit pathogen damage in a tropical tree. Proc. Natl. Acad. Sci. USA 2003, 100, 15649-15654. [CrossRef]

19. Arnold, A.E.; Lewis, L.C. Ecology and Evolution of Fungal Endophytes, and Their Roles against Insects. Insect-Fungal Associations: Ecology and Evolution; Oxford University Press: New York, NY, USA, 2005; pp. 74-96.

20. Griffin, M.R. Beauveria Bassiana, a Cotton Endophyte with Biocontrol Activity against Seedling Disease. Ph.D. Thesis, University of Tennessee, Knoxville, TN, USA, 2007.

21. Ownley, B.H.; Griffin, M.R.; Klingeman, W.E.; Gwinn, K.D.; Moulton, J.K.; Pereira, R.M. Beauveria bassiana: Endophytic colonization and plant disease control. J. Invertebr. Pathol. 2008, 98, 267-270. [CrossRef]

22. Vega, F.E. Insect pathology and fungal endophytes. J. Invertebr. Pathol. 2008, 98, 277-279. [CrossRef]

23. Herre, E.A.; Mejía, L.C.; Kyllo, D.A.; Rojas, E.; Maynard, Z.; Butler, A.; Van Bael, S.A. Ecological implications of anti-pathogen effects of tropical fungal endophytes and mycorrhizae. Ecology 2007, 88, 550-558. [CrossRef]

24. Card, S.; Johnson, L.; Teasdale, S.; Caradus, J. Deciphering endophyte behaviour: The link between endophyte biology and efficacious biological control agents. FEMS Microbiol. Ecol. 2016, 92. [CrossRef] [PubMed]

25. Barra-Bucarei, L.; France, A.; Millas, P. Crossing frontiers: Endophytic entomopathogenic fungi for biological control of plant diseases. In Endophytes for a Growing World; Cambridge University Press: Cambridge, UK, $2019 ;$ p. 67.

26. France, I.; Gerding, G.; Gerding, M.; Sandoval, A. Patogenicidad de una colección de cepas nativas de Metarhizium spp. y Beauveria spp. en Aegorhinus Superciliosus, Asynonychus Cervinus y Otiorhynchus Sulcatus. Agric. Técnica 2000, 60, 205-215. [CrossRef]

27. Moore, D.; Bateman, R.P.; Carey, M.; Prior, C. Long-term storage of Metarhizium flavoviride conidia in oil formulations for the control of locusts and grasshoppers. Biocontrol Sci. Technol. 1995, 5, 193-200. [CrossRef]

28. Resquín-Romero, G.; Garrido-Jurado, I.; Delso, C.; Ríos-Moreno, A.; Quesada-Moraga, E. Transient endophytic colonizations of plants improve the outcome of foliar applications of mycoinsecticides against chewing insects. J. Invertebr. Pathol. 2016, 136, 23-31. [CrossRef] [PubMed]

29. Watanabe, T. Pictorial Atlas of Soil and Seed Fungi: Morphologies of Cultured Fungi and Key to Species; CRC press: Boca Raton, FL, USA, 2010.

30. Hegedus, D.D.; Khachatourians, G.G. Identification and differentiation of the entomopathogenic fungus Beauveria bassiana using polymerase chain reaction and single-strand conformation polymorphism analysis. J. Invertebr. Pathol. 1996, 67, 289-299. [CrossRef]

31. Anees, M.; Tronsmo, A.; Edel-Hermann, V.; Hjeljord, L.G.; Héraud, C.; Steinberg, C. Characterization of field isolates of trichoderma antagonistic against Rhizoctonia Solani. Fungal Biol. 2010, 114, 691-701. [CrossRef]

32. Martin-Hernandez, A.M.; Dufresne, M.; Hugouvieux, V.; Melton, R.; Osbourn, A. Effects of targeted replacement of the tomatinase gene on the interaction of Septoria lycopersici with tomato plants. Mol. Plant-Microbe Interact. 2000, 13, 1301-1311. [CrossRef]

33. Kim, J.-C.; Choi, G.J.; Park, J.-H.; Kim, H.T.; Cho, K.Y. Activity against plant pathogenic fungi of phomalactone isolated from Nigrospora sphaerica. Pest Manag. Sci. Former. Pestic. Sci. 2001, 57, 554-559. [CrossRef]

34. Rueden, C.; Dietz, C.; Horn, M.; Schindelin, J.; Northan, B.; Berthold, M.; Eliceiri, K. ImageJ Ops [Software]. Available online: http://imagej.net/Ops (accessed on 24 July 2017).

35. Di Rienzo, J.A.; Casanoves, F.; Balzarini, M.G.; Gonzalez, L.; Tablada, M.; Robledo, C.W. Info Stat Versión 2011. Grupo InfoStat, FCA, Universidad Nacional de Córdoba, Argentina. Available online: http://www. infostat.com.ar (accessed on 26 September 2018).

36. Powell, W.A.; Klingeman, W.E.; Ownley, B.H.; Gwinn, K.D. Evidence of endophytic Beauveria bassiana in seed-treated tomato plants acting as a systemic entomopathogen to larval Helicoverpa zea (Lepidoptera: Noctuidae). J. Entomol. Sci. 2009, 44, 391-396. [CrossRef]

37. Paul, N.C.; Deng, J.X.; Sang, H.-K.; Choi, Y.-P.; Yu, S.-H. Distribution and antifungal activity of endophytic fungi in different growth stages of chili pepper (Capsicum annuum L.) in Korea. Plant Pathol. J. 2012, 28, 10-19. [CrossRef]

38. Hernawati, H.; Wiyono, S.; Santoso, S. Leaf endophytic fungi of chili (Capsicum annuum) and their role in the protection against Aphis gossypii (Homoptera: Aphididae). Biodiversitas J. Biol. Divers. 2011, 12. [CrossRef]

39. Jaber, L.R.; Araj, S.-E. Interactions among endophytic fungal entomopathogens (Ascomycota: Hypocreales), the green peach aphid Myzus persicae Sulzer (Homoptera: Aphididae), and the aphid endoparasitoid Aphidius colemani Viereck (Hymenoptera: Braconidae). Biol. Control 2018, 116, 53-61. [CrossRef] 
40. Klieber, J.; Reineke, A. The entomopathogen Beauveria bassiana has epiphytic and endophytic activity against the tomato leaf miner Tuta absoluta. J. Appl. Entomol. 2016, 140, 580-589. [CrossRef]

41. Quesada-Moraga, E.; Landa, B.B.; Muñoz-Ledesma, J.; Jiménez-Diáz, R.M.; Santiago-Alvarez, C. Endophytic colonization of Opium poppy, Papaver somniferum, by an entomopathogenic Beauveria bassiana strain. Mycopathologia 2006, 161, 323-329. [CrossRef]

42. Akello, J.; Dubois, T.; Gold, C.S.; Coyne, D.; Nakavuma, J.; Paparu, P. Beauveria bassiana (Balsamo) Vuillemin as an endophyte in tissue culture banana (Musa spp.). J. Invertebr. Pathol. 2007, 96, 34-42. [CrossRef]

43. Tefera, T.; Vidal, S. Effect of Inoculation Method and Plant Growth Medium on Endophytic Colonization of Sorghum by the Entomopathogenic Fungus Beauveria bassiana. BioControl 2009, 54, 663-669. [CrossRef]

44. Jaber, L.R.; Ownley, B.H. Can we use entomopathogenic fungi as endophytes for dual biological control of insect pests and plant pathogens? Biol. Control 2018, 116, 36-45. [CrossRef]

45. Wraight, S.P.; Carruthers, R.I.; Jaronski, S.T.; Bradley, C.A.; Garza, C.J.; Galaini-Wraight, S. Evaluation of the entomopathogenic fungi Beauveria bassiana and Paecilomyces fumosoroseus for microbial control of the silverleaf whitefly, Bemisia argentifolii. Biol. Control 2000, 17, 203-217. [CrossRef]

46. Jaber, L.R.; Enkerli, J. Effect of seed treatment duration on growth and colonization of Vicia faba by endophytic Beauveria bassiana and Metarhizium brunneum. Biol. Control 2016, 103, 187-195. [CrossRef]

47. Behie, S.W.; Jones, S.J.; Bidochka, M.J. Plant tissue localization of the endophytic insect pathogenic fungi Metarhizium and Beauveria. Fungal Ecol. 2015, 13, 112-119. [CrossRef]

48. Barelli, L.; Moonjely, S.; Behie, S.W.; Bidochka, M.J. Fungi with multifunctional lifestyles: Endophytic insect pathogenic fungi. Plant Mol. Biol. 2016, 90, 657-664. [CrossRef] [PubMed]

49. Behie, S.W.; Zelisko, P.M.; Bidochka, M.J. Endophytic insect-parasitic fungi translocate nitrogen directly from insects to plants. Science 2012, 336, 1576-1577. [CrossRef] [PubMed]

50. Parsa, S.; Ortiz, V.; Gómez-Jiménez, M.I.; Kramer, M.; Vega, F.E. Root environment is a key determinant of fungal entomopathogen endophytism following seed treatment in the common bean, Phaseolus vulgaris. Biol. Control 2018, 116, 74-81. [CrossRef] [PubMed]

51. Keller, S.; Zimmermann, G.; Wilding, N.; Collins, N.M.; Hammond, P.M.; Webber, J.F. Mycopathogens of soil insects. In Insect-Fungus Interactions; Academic Press: London, UK, 1989; pp. 239-270.

52. Hajek, A.E. Ecology of terrestrial fungal entomopathogens. In Advances in Microbial Ecology; Springer: Berlin/Heidelberg, Germany, 1997; pp. 193-249.

53. Feng, N.-X.; Yu, J.; Zhao, H.-M.; Cheng, Y.-T.; Mo, C.-H.; Cai, Q.-Y.; Li, Y.-W.; Li, H.; Wong, M.-H. Efficient phytoremediation of organic contaminants in soils using plant-endophyte partnerships. Sci. Total Environ. 2017, 583, 352-368. [CrossRef]

54. Meyling, N.V.; Eilenberg, J. Ecology of the entomopathogenic fungi Beauveria bassiana and Metarhizium anisopliae in temperate agroecosystems: Potential for conservation biological control. Biol. Control 2007, 43, 145-155. [CrossRef]

55. Wagner, B.L.; Lewis, L.C. Colonization of corn, Zea mays, by the entomopathogenic fungus Beauveria bassiana. Appl. Environ. Microbiol. 2000, 66, 3468-3473. [CrossRef]

56. Parine, N.R.; Pathan, A.K.; Sarayu, B.; Nishanth, V.S.; Bobbarala, V. Antibacterial efficacy of secondary metabolites from entomopathogenic fungi Beauveria bassiana. Int. J. Chem. Anal. Sci. 2010, 1, 94-96.

57. Vining, L.C.; Kelleher, W.J.; Schwarting, A.E. Oosporein production by a strain of Beauveria bassiana originally identified as Amanita muscaria. Can. J. Microbiol. 1962, 8, 931-933. [CrossRef]

58. Hamill, R.L.; Higgens, C.E.; Boaz, H.E.; Gorman, M. The structure op beauvericin, a new depsipeptide antibiotic toxic to Artemia salina. Tetrahedron Lett. 1969, 10, 4255-4258. [CrossRef]

59. Suzuki, A.; Kanaoka, M.; Isogai, A.; Tamura, S.; Murakoshi, S.; Ichinoe, M. Bassianolide, a new insecticidal cyclodepsipeptide from Beauveria bassiana and Verticillium lecanii. Tetrahedron Lett. 1977, 18, 2167-2170. [CrossRef]

60. Logrieco, A.; Moretti, A.; Castella, G.; Kostecki, M.; Golinski, P.; Ritieni, A.; Chelkowski, J. Beauvericin production by Fusarium species. Appl. Environ. Microbiol. 1998, 64, 3084-3088. [CrossRef] [PubMed]

61. Nagaoka, T.; Nakata, K.; Kouno, K. Antifungal activity of oosporein from an antagonistic fungus against Phytophthora infestans. Z. Naturforschung C 2004, 59, 302-304. [CrossRef] [PubMed]

62. Wang, Q.; Xu, L. Beauvericin, a bioactive compound produced by fungi: A short review. Molecules 2012, 17, 2367-2377. [CrossRef] [PubMed] 
63. Feng, P.; Shang, Y.; Cen, K.; Wang, C. Fungal biosynthesis of the bibenzoquinone oosporein to evade insect immunity. Proc. Natl. Acad. Sci. USA 2015, 112, 11365-11370. [CrossRef]

64. Orole, O.O.; Adejumo, T.O. Activity of fungal endophytes against four maize wilt pathogens. Afr. J. Microbiol. Res. 2009, 3, 969-973.

65. Bark, Y.G.; Lee, D.G.; Kang, S.C.; Kim, Y.H. Antibiotic properties of an entomopathogenic fungus, Beauveria bassiana, on Fusarium oxysporum and Botrytis cinerea. Korean J. Plant Pathol. 1996, 12, 245-250.

66. Renwick, A.; Campbell, R.; Coe, S. Assessment of in vivo screening systems for potential biocontrol agents of Gaeumannomyces graminis. Plant Pathol. 1991, 40, 524-532. [CrossRef]

67. Ownley, B.H.; Pereira, R.M.; Klingeman, W.E.; Quigley, N.B.; Leckie, B.M. Beauveria bassiana, a dual purpose biocontrol organism, with activity against insect pests and plant pathogens. In Emerging Concepts in Plant Health Management; Research Signpost: Thiruvananthapuram, India, 2004; pp. 255-269.

68. Vega, F.E.; Goettel, M.S.; Blackwell, M.; Chandler, D.; Jackson, M.A.; Keller, S.; Koike, M.; Maniania, N.K.; Monzon, A.; Ownley, B.H. Fungal entomopathogens: New insights on their ecology. Fungal Ecol. 2009, 2, 149-159. [CrossRef]

69. Jaber, L.R. Grapevine leaf tissue colonization by the fungal entomopathogen Beauveria bassiana. L. and its effect against downy mildew. BioControl 2015, 60, 103-112. [CrossRef]

70. El Kichaoui, A.; Elnabris, K.; Shafie, A.; Fayyad, N.; Arafa, M.; El Hindi, M. Development of Beauveria bassiana based bio-fungicide against Fusarium wilt pathogens for Capsicum annuum, a promising approach toward vital biocontrol industry in Gaza strip. IUG J. Nat. Stud. 2017, 25, 183-190.

71. Jaber, L.R.; Salem, N. Endophytic colonization of squash by the fungal entomopathogen Beauveria bassiana (Ascomycota: Hypocreales) for managing Zucchini Yellow Mosaic Virus in cucurbits. Biocontrol Sci. Technol. 2014, 24, 1096-1109. [CrossRef]

(C) 2019 by the authors. Licensee MDPI, Basel, Switzerland. This article is an open access article distributed under the terms and conditions of the Creative Commons Attribution (CC BY) license (http://creativecommons.org/licenses/by/4.0/). 